\title{
High Surface Area Ceria for CO Oxidation Prepared from Cerium $t$-Butoxide by Combined Sol-Gel and Solvothermal Processing
}

\author{
Jingxia Yang • Liliana Lukashuk $\cdot$ Hao Li • \\ Karin Föttinger · Günther Rupprechter • \\ Ulrich Schubert
}

Received: 2 October 2013/Accepted: 6 November 2013/Published online: 17 December 2013

(C) The Author(s) 2013. This article is published with open access at Springerlink.com

\begin{abstract}
CeO}_{2}$ was synthesized by combined sol-gel and solvothermal processing of gels obtained from acetaldoximate-modified cerium(IV) $t$-butoxide in the presence of the non-ionic surfactant Pluronic F127. The use of cerium(IV) $t$-butoxide as precursor contrasts very favorably with the often used ceric ammonium nitrate and results in more reliable and tailorable properties of the final materials. The kind of post-synthesis treatment of the gels and the composition of the precursor mixture proved to be crucial for obtaining high surface area ceria with a high $\mathrm{Ce}^{3+}$ proportion. Calcination in air or under nitrogen was compared with solvothermal treatment in ethanol or water and a combination of solvothermal treatment and calcination. The obtained materials are composed of 3.5-5.5 nm ceria nanoparticles. The highest specific surface area of $277 \mathrm{~m}^{2} / \mathrm{g}$ was obtained after solvothermal treatment, and $180 \mathrm{~m}^{2} / \mathrm{g}$ when solvothermal treatment was followed by calcination in air to remove residual organic groups. The highest $\mathrm{Ce}^{3+}$ proportion was $18 \%$ after solvothermal treatment in ethanol and additional calcination in air. $\mathrm{CO}$ oxidation on selected samples indicated that activity scaled with surface area and thus was largest for samples solvothermally treated in ethanol. The reaction rate of the best sample was about 75-times larger than that of commercial ceria.
\end{abstract}

Keywords Ceria $\cdot$ Cerium butoxide $\cdot$ Sol-gel processing $\cdot$ Solvothermal treatment $\cdot \mathrm{CO}$ oxidation

J. Yang · L. Lukashuk - H. Li - K. Föttinger - G. Rupprechter · U. Schubert $(\bowtie)$

Institute of Materials Chemistry, Vienna University of

Technology, Getreidemarkt 9, 1060 Wien, Austria

e-mail: ulrich.schubert@tuwien.ac.at

\section{Introduction}

Ceria $\left(\mathrm{CeO}_{2}\right)$ has received attention in environmental catalysis because of its high oxygen storage-release capacity associated with the $\mathrm{Ce}^{4+} / \mathrm{Ce}^{3+}$ redox cycle [1]. It was suggested that nano-scaled ceria with abundant oxygen vacancies would further enhance the catalytic activity $[2,3]$.

Various methods have been employed to synthesize $\mathrm{CeO}_{2}$, including the sol-gel method [4]. The latter has many advantages because the materials composition and texture can be influenced by the proper choice of precursors and processing conditions. Inorganic cerium salts, such as $\mathrm{Ce}\left(\mathrm{NO}_{3}\right)_{3} \cdot 6 \mathrm{H}_{2} \mathrm{O}$ [5-9] $\mathrm{CeCl}_{3} \cdot 7 \mathrm{H}_{2} \mathrm{O}$ [10] or ceric ammonium nitrate $\left(\mathrm{NH}_{4}\right)_{2}\left[\mathrm{Ce}\left(\mathrm{NO}_{3}\right)_{6}\right]$ (CAN) [11], were mainly used as precursors for sol-gel processing of ceria (including the citrate-gel route) because they are commercially available. Qi et al. [12] found that the choice of the precursor $\left[\mathrm{Ce}\left(\mathrm{NO}_{3}\right)_{3}\right.$ and $\left.\left(\mathrm{NH}_{4}\right)_{2} \mathrm{Ce}\left(\mathrm{NO}_{3}\right)_{6}\right]$ influenced the structure, surface state, reducibility and $\mathrm{CO}$ oxidation activity of $\mathrm{Cu}$ doped $\mathrm{CeO}_{2}$ materials.

Cerium alkoxides, $\mathrm{Ce}(\mathrm{OR})_{3}$ or $\mathrm{Ce}(\mathrm{OR})_{4}$, are less often employed as precursors because they are not easily available commercially and more reactive to humidity. Nevertheless, metal alkoxides have often advantages because the materials textures and properties can be easily modified by varying the reaction parameters. Cerium alkoxides were used, for example, to prepare ceria thin films $[13,14]$ or bimetallic oxides [15-17].

Apart from the precursor, the post-synthesis treatment of the gels is also an important parameter influencing the materials properties. Gels obtained by sol-gel processing are often heat-treated in air, sometimes also in $\mathrm{N}_{2}$ or a combination of both, to remove residual organic groups. Recently, a combined sol-gel and solvothermal process was applied for the preparation of titania which 
possessed a special microstructure with high surface area [18, 19].

In the work reported here, the influence of different precursors (CAN and cerium(IV) $t$-butoxide $\left(\mathrm{Ce}(\mathrm{O} t \mathrm{Bu})_{4}\right)$, $\mathrm{CeB}$ ) and of different post-synthesis treatment of the gels on the morphology and microstructure of ceria was investigated. Furthermore, the catalytic activity of various $\mathrm{CeO}_{2}$ samples for $\mathrm{CO}$ oxidation was tested, with the specific surface area $\left(\mathrm{S}_{\mathrm{BET}}\right)$ and the $\mathrm{Ce}^{3+}$ (surface) concentration being very important parameters.

In previous work on high surface area titania, some of us had shown that modification of the metal alkoxide with acetaldoxime (AO) resulted in materials with superior properties, especially when combined with the nonionic surfactant Pluronic F127 as a pore-forming agent [20]. The impact of both precursor modification and surfactant-assisted sol-gel processing on the materials properties, especially porosity and surface area, was discussed there in detail. We have therefore used AO and F127 also in this work. Substitution of metal alkoxides by bidentate ligands (such as AO) slows down the reaction rates and results in additional porosity/surface area upon calcination of the gels. Although the oximate-modified cerium alkoxide precursor was prepared in situ according to Eq. 1, it is reasonable to assume that the composition and structure of the precursors is the same as that of oximate-substituted zirconium alkoxides, $\mathrm{Zr}(\mathrm{OR})_{4-\mathrm{x}}(\mathrm{O}-$ $\left.\mathrm{N}=\mathrm{CRR}^{\prime}\right)_{\mathrm{x}}[21]$, given the general similarity of $\mathrm{Zr}$ and $\mathrm{Ce}$ alkoxides.

$$
\begin{aligned}
\mathrm{Ce}(\mathrm{OR})_{4}+\mathrm{x} \mathrm{RR} \mathrm{RR}^{\prime}=\mathrm{N}-\mathrm{OH} \rightarrow & \mathrm{Ce}(\mathrm{OR})_{4-\mathrm{x}}\left(\mathrm{O}-\mathrm{N}=\mathrm{CRR}^{\prime}\right)_{\mathrm{x}} \\
& +\mathrm{x} \mathrm{ROH}
\end{aligned}
$$

\section{Experimental}

All solvents were dried by standard methods, and all experiments involving metal alkoxides were carried out under moisture- and oxygen-free argon using standard Schlenk or glove box techniques. $\left(\mathrm{NH}_{4}\right)_{2}\left[\mathrm{Ce}\left(\mathrm{NO}_{3}\right)_{6}\right]$ was obtained from Alfa-Aesar and used as received. Commercial $\mathrm{CeO}_{2}$ powder from Aldrich was used for comparison.

\subsection{Synthesis of Cerium $t$-Butoxide}

Cerium(IV) $t$-butoxide $\left(\mathrm{Ce}(\mathrm{O} t \mathrm{Bu})_{4}, \mathrm{CeB}\right)$ was synthesized according to the literature from $\left(\mathrm{NH}_{4}\right)_{2}\left[\mathrm{Ce}\left(\mathrm{NO}_{3}\right)_{6}\right](\mathrm{CAN})$ and sodium $t$-butoxide in 1,2-dimethoxyethane [22, 23]. The oily residue obtained after removal of the solvent was used directly for sol-gel processing without further purification. X-ray photoelectron spectra (XPS) proved that the sample contained no residual sodium from the preparation.
$2.2 \mathrm{CeO}_{2}$ Synthesis

Sols were prepared from CeB, AO, F127 and 1,2-dimethoxyethane (DME) in a 1:2:0.005:40 ratio. In some reactions no F127 was used. In a typical experiment, $5 \mathrm{mmol}$ of $\mathrm{CeB}$ was dissolved in $10 \mathrm{~mL}$ of DME, then $10 \mathrm{mmol}$ of AO was added and the mixture was stirred for $30 \mathrm{~min}$. After addition of $0.025 \mathrm{mmol}$ of F127 the mixture was stirred for another hour. No water was added at this stage. The sols were then deposited onto glass sheets $\left(20 \times 30 \mathrm{~cm}^{2}\right)$, which had been cleaned with $10 \% \mathrm{NaOH}$, $i \mathrm{PrOH}$ and acetone and dried at $100{ }^{\circ} \mathrm{C}$. The as-deposited films were exposed to ambient humidity at room temperature for $24 \mathrm{~h}$. The obtained solids were then scraped off with a razor blade to get a gel powder and directly treated by one of the following methods:

- Holding at $500{ }^{\circ} \mathrm{C}$ in air for $2 \mathrm{~h}$ in an $\mathrm{Al}_{2} \mathrm{O}_{3}$ crucible; heating rate $2 \% \mathrm{~min}$ (AC).

- Solvothermal treatment (ST) at $200{ }^{\circ} \mathrm{C}$ for $6 \mathrm{~h}(\mathrm{ST})$ in a $60 \mathrm{~mL}$ autoclave with $30 \mathrm{~mL}$ solvent (gel prepared from $5 \mathrm{mmol}$ of $\mathrm{CeB})$. Two different solvents were used, viz. EtOH (STE) and $\mathrm{H}_{2} \mathrm{O}(\mathrm{STH})$.

- ST, followed by calcination as described for AC (STAC) (Scheme 1).

The labeling of the samples is as follows: (i) precursors (CeB, AO and/or F127), (ii) post synthesis treatment (AC, STE, STH). For example, CeB/AO/F127-STE-AC is a sample prepared from a mixture of $\mathrm{CeB}, \mathrm{AO}$ and $\mathrm{F} 127$, followed by ST in ethanol (STE) and calcination in air (AC).

\subsection{Characterization}

Thermogravimetric analysis (TGA) was performed on a Netzsch Iris TG $209 \mathrm{C}$ in a platinum crucible in synthetic air with a heating rate of $10{ }^{\circ} \mathrm{C} / \mathrm{min}$. Infrared spectra (IR) were recorded on a Bruker Tensor 27 working in ATR Micro Focusing MVP-QL with a ZnSe crystal, using OPUS software version 4.0 for analysis.

X-Ray powder diffraction (XRD) measurements were performed on a Philips X'Pert diffractometer using $\mathrm{Cu}-\mathrm{K}_{\alpha}$ radiation $(\lambda=1.5406 \AA)$. Scanning electron micrographs (SEM) were obtained on a Quanta 200 (FEI) equipped with a Genesis (EDAX) energy dispersive spectrometer, with a voltage of $7.5 \mathrm{kV}$. XPS were measured on a Specs XPS system (XR 50 Mg/Al-Dual Anode, PHOIBOS 150 hemispherical analyzer).

High resolution transmission electron micrographs (HRTEM) were recorded on a TECNAI F20 operated at $200 \mathrm{kV}$. Before the measurements, the samples were ultrasonically dispersed in $\mathrm{EtOH}$ for $30 \mathrm{~min}$, and then deposited on copper grids covered with carbon films. 
Scheme 1 Schematic synthesis protocol for $\mathrm{CeO}_{2}$ by combination of sol-gel and solvothermal processing

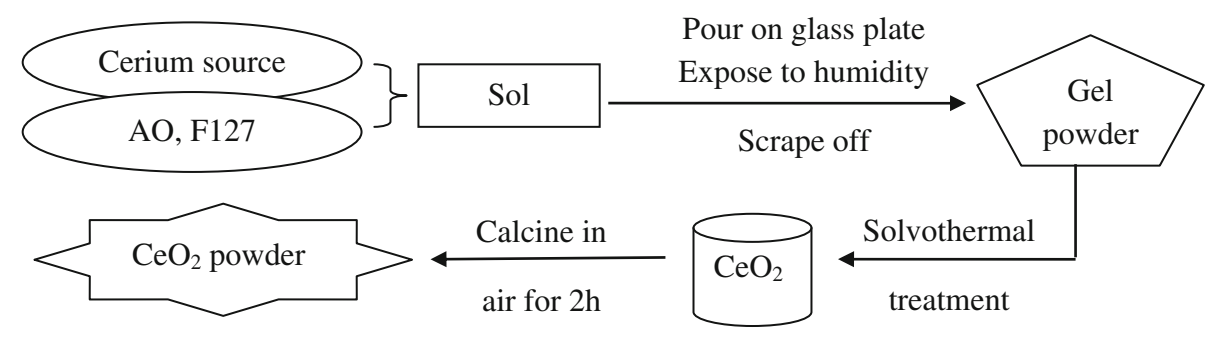

Nitrogen sorption measurements were performed on an ASAP 2020 (Micromeritics). The samples were degassed in vacuum at room temperature for at least $5 \mathrm{~h}$ prior to measurement. The total surface area was calculated according to Brunauer, Emmett and Teller (BET), and the pore size distribution (from the desorption branch) according to Barrett, Joyner and Halenda (BJH).

\subsection{Catalytic Activity}

The $\mathrm{CO}$ oxidation reaction was performed in a continuousflow fixed-bed quartz reactor under atmospheric pressure. An amount of $20 \mathrm{mg}$ of each sample was loaded into the reactor and pretreated with synthetic air $(30 \mathrm{~mL} / \mathrm{min})$ at $200{ }^{\circ} \mathrm{C}$ for $40 \mathrm{~min}$ (heating rate $10{ }^{\circ} \mathrm{C} / \mathrm{min}$ ). Then the sample was cooled to $30{ }^{\circ} \mathrm{C}$ in flowing synthetic air, and a mixture of $5 \mathrm{vol} \% \mathrm{CO}, 10 \mathrm{vol} \% \mathrm{O}_{2}$ and $85 \mathrm{vol} \% \mathrm{He}$ (total flow $50 \mathrm{~mL} / \mathrm{min}$ ) was introduced. The system was then heated to $650{ }^{\circ} \mathrm{C}$ with a ramping rate of $5{ }^{\circ} \mathrm{C} / \mathrm{min}$. The concentrations of $\mathrm{CO}$ and $\mathrm{CO}_{2}$ in the outlet streams were monitored by gas chromatography with a HP-PLOT Q column and a flame ionization detector.

$\mathrm{CO}$ temperature-programmed reaction (CO-TPR) over ca. $20 \mathrm{mg}$ samples were also performed in a continuousflow fixed-bed quartz reactor under atmospheric pressure. The catalyst samples were pre-treated with synthetic air at $200{ }^{\circ} \mathrm{C}$ for $40 \mathrm{~min}$ (heating step $10{ }^{\circ} \mathrm{C} / \mathrm{min}$ ) at a flow rate of $30 \mathrm{~mL} / \mathrm{min}$. After cooling to room temperature the samples were exposed to a mixture of $5 \mathrm{vol} \% \mathrm{CO}$ and $95 \mathrm{vol} \% \mathrm{He}$ (total flow $50 \mathrm{~mL} / \mathrm{min}$ ) at room temperature. Then the system was ramped up to $900{ }^{\circ} \mathrm{C}$ at a heating rate of $10^{\circ} \mathrm{C} / \mathrm{min}$. The gas stream was analysed by an online quadrupole mass spectrometer (QMS) (Prisma Plus QMG 220, Pfeiffer Vacuum) equipped with a Faraday detector.

\section{Results and Discussion}

\subsection{Gel Preparation}

Sols were prepared from $\mathrm{CeB}$ (or CAN), AO, F127 and 1,2-dimethoxyethane (DME) in a 1:2:0.005:40 ratio. In some reactions no F127 was added to check the influence of the surfactant. Gelation was induced by exposure to ambient humidity at room temperature. The obtained solid gels were then treated by different methods, viz. calcination in air (AC), ST in EtOH (STE) or $\mathrm{H}_{2} \mathrm{O}(\mathrm{STH})$, or ST, followed by calcination (ST-AC) (see Sect. 2.2).

When $\left(\mathrm{NH}_{4}\right)_{2}\left[\mathrm{Ce}\left(\mathrm{NO}_{3}\right)_{6}\right](\mathrm{CAN})$ was used, the onset temperature was about $230{ }^{\circ} \mathrm{C}$ and the gel decomposed completely below $300{ }^{\circ} \mathrm{C}$ with a weight loss of about $72 \%$. This indicates that part of the material was lost during the TGA measurements due to deflagration. It should be pointed out that samples obtained from CAN sometimes exploded upon calcination. The solid obtained from CAN after sol-gel processing was water-soluble; thus no network had been formed with ambient moisture. The exothermic decomposition of CAN and the solubility of the obtained gel render CAN unappealing as precursor. For this reason CAN-derived samples will no longer be considered in the following.

In contrast, when $\mathrm{CeB}$ was used as a cerium precursor, the onset temperature in TGA was about $495^{\circ} \mathrm{C}$, and decomposition was complete at about $600{ }^{\circ} \mathrm{C}$, with $22 \%$ weight loss. The $\mathrm{X}$-ray diffractogram after calcination (sample $\mathrm{CeB} / \mathrm{AO} / \mathrm{F} 127-\mathrm{AC}$ ) showed that the sample was phase-pure ceria (PDF-No. 34-0394) with a particle size of $9.2 \mathrm{~nm}$, as calculated by the Scherrer equation based on the strongest reflection at $28.6^{\circ}$.

We also tested whether thermolysis at $500{ }^{\circ} \mathrm{C}$ in $\mathrm{N}_{2}$ for $3 \mathrm{~h}$, followed by calcination in air for $2 \mathrm{~h}$ would result in significantly different materials properties. The particle size was only slightly smaller $(8.6 \mathrm{~nm})$ and the specific surface area (see below) slightly higher. For this reason, only calcination in air was used in the following.

\subsection{Influence of Different Post-synthesis Treatments}

The results of BET measurements of the gels obtained from $\mathrm{CeB}$ and treated differently after gelation are summarized in Table 1. The AC sample had $\mathrm{N}_{2}$ sorption isotherms between type IV and III according to the IUPAC definition [24], corresponding to meso-/macro-porous materials. Table 1 shows that for AC calcination, the specific surface area $\left(\mathrm{S}_{\mathrm{BET}}\right)$ was only $8.6 \mathrm{~m}^{2} / \mathrm{g}$ without $\mathrm{F} 127$ and $12.8 \mathrm{~m}^{2} / \mathrm{g}$ with F127, i.e. it was not too much changed by the presence of F127 in this system. The specific surface area is too small to be interesting for catalytic applications. 
Table 1 BET results for $\mathrm{CeB}: \mathrm{AO}=1: 2$ samples with different postsynthesis treatment

\begin{tabular}{llll}
\hline F127 & Calcination & $\mathrm{S}_{\text {BET }}\left(\mathrm{m}^{2} / \mathrm{g}\right)^{\mathrm{a}}$ & $\mathrm{D}_{\text {BJH }}(\mathrm{nm})^{\mathrm{b}}$ \\
\hline- & AC & 8.6 & 7.0 \\
+ & AC & 12.8 & 12.1 \\
+ & STE & 277.0 & 3.4 \\
+ & STH & 133.6 & 5.5 \\
\hline
\end{tabular}

${ }^{a} \mathrm{~S}_{\mathrm{BET}}$ : BET surface area, error $\pm 5 \%$ (from repeated experiments)

${ }^{\mathrm{b}} \mathrm{D}_{\mathrm{BJH}}$ : $\mathrm{BJH}$ desorption pore diameter, $\pm 0.5 \mathrm{~nm}$ (from repeated experiments)

Because standard calcination did not provide samples with high surface areas, ST was tested, and both $\mathrm{EtOH}$ and $\mathrm{H}_{2} \mathrm{O}$ were used as ST solvent (samples labeled STE and $\mathrm{STH}$, respectively). The $\mathrm{N}_{2}$ sorption isotherms and pore size distributions of $\mathrm{CeB} / \mathrm{AO} / \mathrm{F} 127-\mathrm{ST}$ are shown in Fig. 1, and the derived parameters are summarized in Table 1 . The shape of the isotherms showed that $\mathrm{CeB} / \mathrm{AO} / \mathrm{F} 127-\mathrm{STH}$ is mesoporous with a specific surface area of $133.6 \mathrm{~m}^{2} / \mathrm{g}$, while $\mathrm{CeB} / \mathrm{AO} / \mathrm{F} 127-\mathrm{STE}$ is microporous with a very high surface area of $277.0 \mathrm{~m}^{2} / \mathrm{g}$. The surface area of the materials can thus be strongly improved by ST treatment, and the used solvent had a significant influence on the surface area and especially the pore size distribution (Fig. 1 right).

\subsection{Influence of the Sol Composition}

After evaluation of the best post-synthesis treatment, the influence of the sol composition on the materials properties was investigated in more detail. To this end, the following experiments were performed:

- $\mathrm{CeB}$ : only $\mathrm{CeB}$ in DME in the ratio CeB:DME = 1:40.

- CeB/AO: $\mathrm{CeB}$ and $\mathrm{AO}$ in DME in the ratio of $\mathrm{CeB}: \mathrm{AO}: \mathrm{DME}=1: 2: 40$.

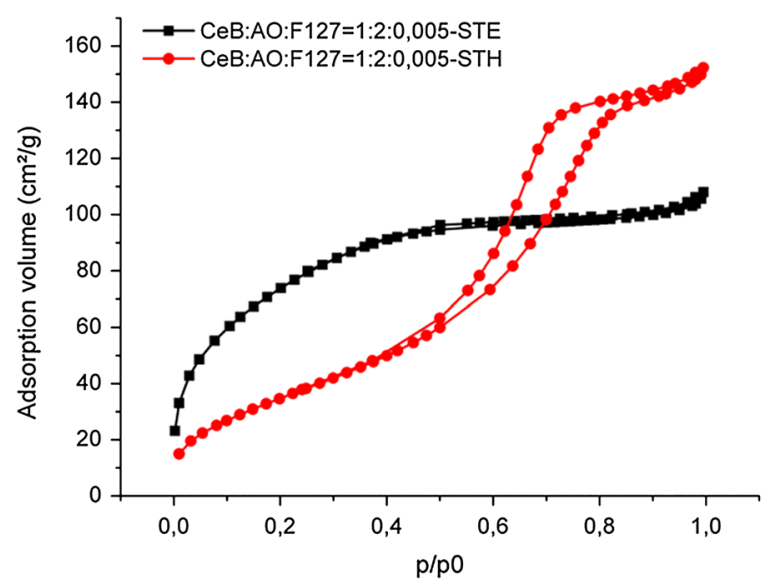

- CeB/F127: $\mathrm{CeB}$ and F127 in DME in the ratio CeB:F127:DME = 1:0.005:40.

- $\mathrm{CeB} / \mathrm{AO} / \mathrm{F} 127: \mathrm{CeB}, \mathrm{AO}$ and F127 in DME in the ratio $\mathrm{CeB}: \mathrm{AO}: \mathrm{F} 127: \mathrm{DME}=1: 2: 0.005: 40$.

The samples were solvothermally treated (STE or STH), with all other preparation parameters being the same.

TGA measurements indicated that all samples still contained organic groups after ST, as expected. The weight loss of the samples treated in EtOH was almost the same $(11.5 \pm 1.0 \%$, Fig. 2, left $)$. When the solvent was changed to $\mathrm{H}_{2} \mathrm{O}$, however, the weight loss was much lower ( $4.0 \pm 0.2 \%$, Fig. 2, right). It can be concluded that during hydrothermal treatment, the organic constituents attached on the gel particles are already cleaved to a much larger extent than in the case of ST in ethanol.

This conclusion was confirmed by IR measurements. When EtOH was used as a solvent (Fig. 3 left), all spectra showed strong bands at about $1300-1650 \mathrm{~cm}^{-1}(\mathrm{C}-\mathrm{O}, \mathrm{C}=\mathrm{O}, \mathrm{COO})$ and $800-1000 \mathrm{~cm}^{-1}(\mathrm{Ce}-\mathrm{O}-\mathrm{Ce})$, and weak bands at $2954\left(\mathrm{CH}_{3}\right)$ and $2845 \mathrm{~cm}^{-1}\left(\mathrm{CH}_{2}\right)$. The strong bands at 1635,1541 and $1258 \mathrm{~cm}^{-1}$ indicated the presence of larger proportions of carboxylate groups. The appearance of such groups on the surface of ceria nanoparticles after ST in alcohols was reported by Slostowski et al. [25]. When $\mathrm{H}_{2} \mathrm{O}$ was used as solvent (Fig. 3, right), only strong bands at about $1000 \mathrm{~cm}^{-1}$ were observed. Generally, the fundamental stretching bands $(\mathrm{Ce}-\mathrm{O})$ for $\mathrm{CeO}_{2}$ materials are in the range $400-500 \mathrm{~cm}^{-1}$ [26]. Thus, the observed bands at $800-1000 \mathrm{~cm}^{-1}$ can be attributed to the overtones. They may slightly shift depending on the surface groups. The weak bands at 1564 and $1264 \mathrm{~cm}^{-1}$ indicated that there was only a small carboxylate proportion.

The results of $\mathrm{N}_{2}$ sorption measurements are given in Table 2. For the STE samples the surface areas were in the following order: CeB/AO/F127-STE $\left(277 \mathrm{~m}^{2} / \mathrm{g}\right)>\mathrm{CeB} /$ F127-STE $\left(247 \mathrm{~m}^{2} / \mathrm{g}\right)>$ CeB/AO-STE $\left(210 \mathrm{~m}^{2} / \mathrm{g}\right)>$ CeB-STE

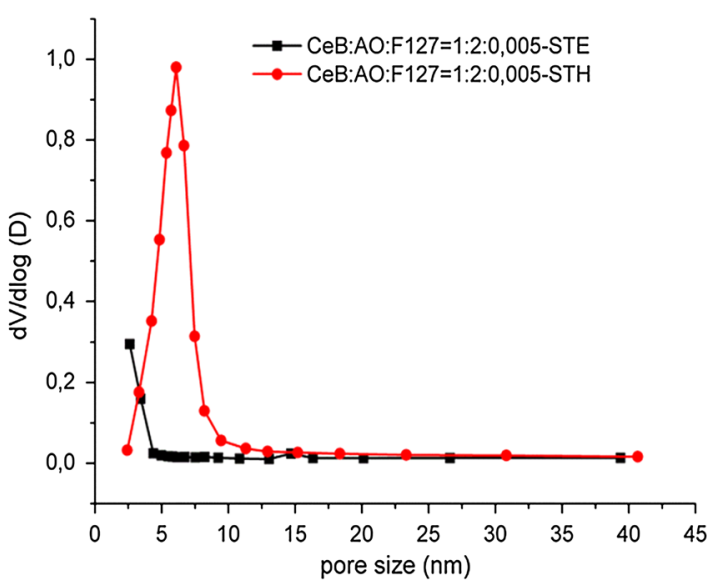

Fig. $1 \mathrm{~N}_{2}$ adsorption-desorption isotherms (left) and pore size distribution (right) for different sample after ST 

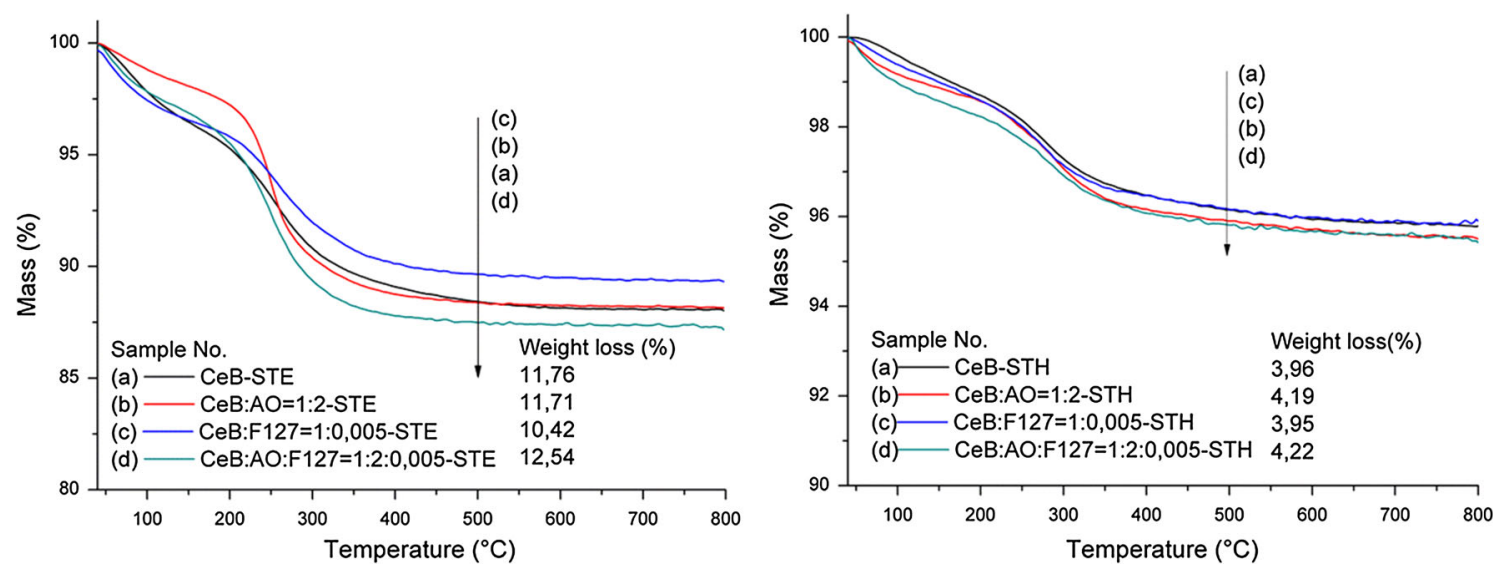

Fig. 2 TGA curves for different CeB samples treated by STE (left) or STH (right)

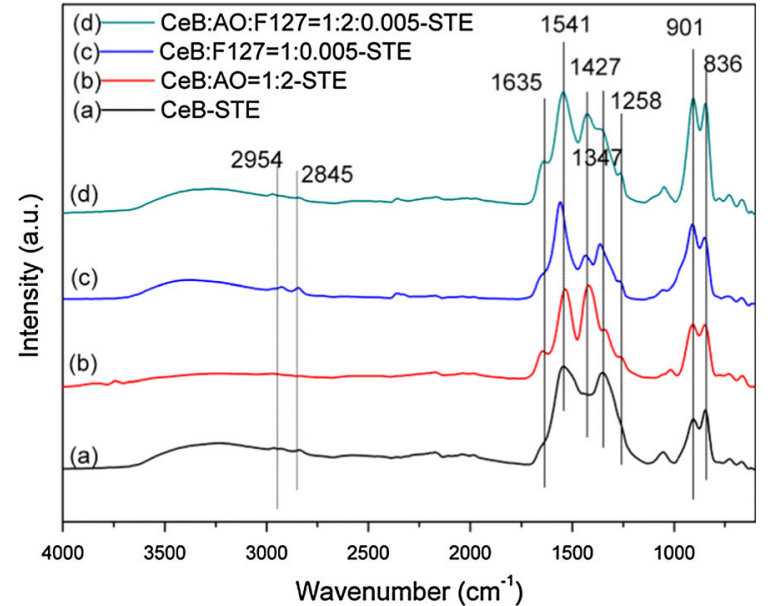

Fig. 3 IR spectra of CeB samples treated by STE (left) or STH (right)

$\left(193 \mathrm{~m}^{2} / \mathrm{g}\right)$. When $\mathrm{H}_{2} \mathrm{O}$ was used as solvent, however, the surface area was $\mathrm{CeB} / \mathrm{F} 127-\mathrm{STH}\left(181 \mathrm{~m}^{2} / \mathrm{g}\right)>\mathrm{CeB} / \mathrm{AO}-$ STH $\quad\left(167 \mathrm{~m}^{2} / \mathrm{g}\right)>\mathrm{CeB}-\mathrm{STH} \quad\left(146 \mathrm{~m}^{2} / \mathrm{g}\right)>\mathrm{CeB} / \mathrm{AO} /$ F127-STE $\left(133 \mathrm{~m}^{2} / \mathrm{g}\right)$. Except $\mathrm{CeB} / \mathrm{AO} / \mathrm{F} 127-\mathrm{ST}$, the sequence was similar for both series. The surface areas for the STE samples were about $50 \mathrm{~m}^{2} / \mathrm{g}$ higher than that of STH samples, which may be due to the residual organic groups during solvothermal processing with $\mathrm{EtOH}$, as reported earlier for ceria [25] and also indicated by the IR spectra (Fig. 3, left). The organic groups therefore appear to stabilize smaller particles and a higher porosity, and thus result in higher surface areas.

When EtOH was used, only $\mathrm{CeB} / \mathrm{F} 127$ had a very narrow pore size distribution in the mesoporous range (Fig. 4). When $\mathrm{H}_{2} \mathrm{O}$ was used, all samples except CeB-STH had almost the same pore size distribution, with the narrowest for $\mathrm{CeB} / \mathrm{AO} / \mathrm{F} 127$. The use of $\mathrm{AO}$ for modification of the starting cerium alkoxide had different influence on the pore size and the specific surface area when different ST solvents were used.

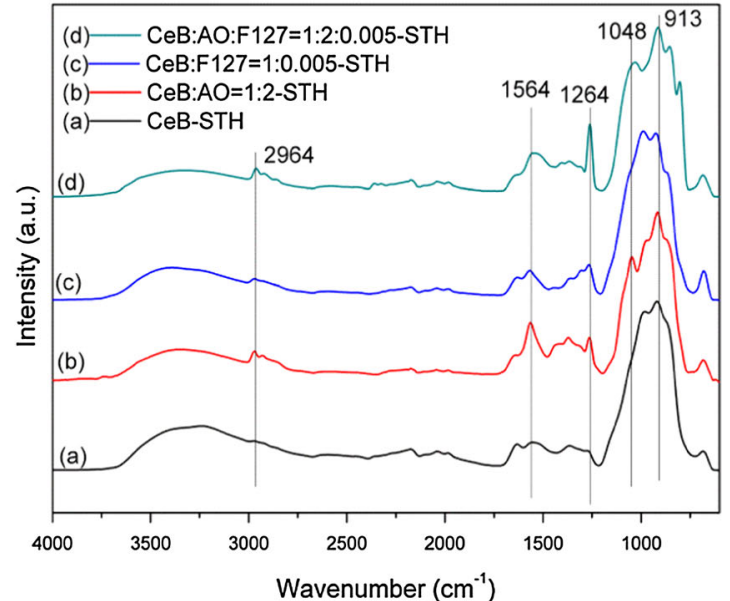

\subsection{Calcination After Solvothermal Treatment}

The previous experiments had shown that residual organic groups were present after ST, especially in ethanol. To check how removal of the residual organic groups would influence the properties of the materials, selected samples were calcined in air after ST. The IR spectra of $\mathrm{CeB} / \mathrm{AO} /$ F127-STE after calcination at different temperatures are shown in Fig. 5, left. The carboxylate groups were almost completely decomposed after heat treatment at $300{ }^{\circ} \mathrm{C}$, as already indicated by the TGA measurements (Fig. 2), and only small residues remained after temperature treatment above $500{ }^{\circ} \mathrm{C}$. The $\mathrm{Ce}-\mathrm{O}-\mathrm{Ce}$ region had a new band at $986 \mathrm{~cm}^{-1}$ after calcination at $300{ }^{\circ} \mathrm{C}$. This band became stronger with increasing temperature, while the original bands at 924 and $852 \mathrm{~cm}^{-1}$ were only slightly reduced.

The changes of $\mathrm{CeB} / \mathrm{AO} / \mathrm{F} 127-\mathrm{STH}$ were similar to that of the STE samples (Fig. 5, right). Significant differences between the STE-AC and the STH-AC samples were, however, that the new band at $990 \mathrm{~cm}^{-1}$ of the STH-AC 
Table 2 BET and XRD results summary of samples prepared by ST and ST-AC treatment

\begin{tabular}{|c|c|c|c|c|c|c|}
\hline \multirow[t]{2}{*}{$\begin{array}{l}\text { ST } \\
\text { solvent }\end{array}$} & \multirow[t]{2}{*}{$\begin{array}{l}\text { Sol } \\
\text { composition }\end{array}$} & \multicolumn{2}{|c|}{ ST series } & \multicolumn{2}{|c|}{$\begin{array}{l}\text { ST-AC500 }{ }^{\circ} \mathrm{C} \\
\text { series }\end{array}$} & \multirow[b]{2}{*}{$\begin{array}{l}\mathrm{P}_{\mathrm{XRD}}^{\mathrm{c}} \\
(\mathrm{nm})\end{array}$} \\
\hline & & $\begin{array}{l}\mathrm{S}_{\mathrm{BET}} \\
\left(\mathrm{m}^{2} / \mathrm{g}\right)^{\mathrm{a}}\end{array}$ & $\begin{array}{l}\mathrm{D}_{\mathrm{BJH}} \\
(\mathrm{nm})^{\mathrm{b}}\end{array}$ & $\begin{array}{l}\mathrm{S}_{\mathrm{BET}} \\
\left(\mathrm{m}^{2} / \mathrm{g}\right)^{\mathrm{a}}\end{array}$ & $\begin{array}{l}\mathrm{D}_{\mathrm{BJH}} \\
(\mathrm{nm})^{\mathrm{b}}\end{array}$ & \\
\hline \multirow[t]{4}{*}{$\mathrm{EtOH}$} & $\mathrm{CeB}$ & 193.3 & 4.5 & 22.4 & 5.0 & 4.9 \\
\hline & $\mathrm{CeB} / \mathrm{AO}$ & $210.5^{*}$ & $3.2 *$ & $92.4 *$ & $3.1 *$ & 4.3 \\
\hline & $\mathrm{CeB} / \mathrm{F} 127$ & 246.9 & 6.2 & 153.3 & 5.3 & 3.9 \\
\hline & $\mathrm{CeB} / \mathrm{AO} / \mathrm{F} 127$ & $277.0^{*}$ & $3.4 *$ & $88.9 *$ & $3.9 *$ & 4.0 \\
\hline \multirow[t]{4}{*}{$\mathrm{H}_{2} \mathrm{O}$} & $\mathrm{CeB}$ & 146.6 & 3.8 & 143.3 & 3.7 & 3.6 \\
\hline & $\mathrm{CeB} / \mathrm{AO}$ & 167.1 & 5.7 & 165.8 & 5.6 & 4.4 \\
\hline & $\mathrm{CeB} / \mathrm{F} 127$ & 181.3 & 4.6 & 178.5 & 4.7 & 4.4 \\
\hline & $\mathrm{CeB} / \mathrm{AO} / \mathrm{F} 127$ & $133.6^{*}$ & $5.5^{*}$ & $132.4^{*}$ & $5.4^{*}$ & 5.3 \\
\hline
\end{tabular}

${ }^{a}$ BET surface area; error $\pm 5 \%$

b BJH desorption pore diameter; $\pm 0.5 \mathrm{~nm}$ for STE series, $\pm 0.1 \mathrm{~nm}$ for STH series

${ }^{\mathrm{c}}$ Crystallite particle size calculated by Scherrer equation from XRD

* Samples were synthesized at least two times, and the average values are given here

sample became much stronger during calcination than that of the STE-AC sample, while the original bands at 924 and $852 \mathrm{~cm}^{-1}$ and other small bands became weaker.

The experiment indicated that calcination in air at $500{ }^{\circ} \mathrm{C}$ removes most of the residual organic groups without causing excessive sintering of the materials. For the following experiments, the samples were therefore treated at $500{ }^{\circ} \mathrm{C}$.

BET measurements after calcination (Table 2) showed that the surface area and average pore size of the STH samples were not significantly changed. In contrast, the surface area of the STE-AC samples was significantly reduced compared with the corresponding STE samples while the average pore sizes only changed slightly. For example, $\mathrm{CeB} / \mathrm{AO} / \mathrm{F} 127-\mathrm{STE}$ had a surface area of $277 \mathrm{~m}^{2} /$ $\mathrm{g}$ and an average pore size of $3.4 \mathrm{~nm}$, but the corresponding values of $\mathrm{CeB} / \mathrm{AO} / \mathrm{F} 127-\mathrm{STE}-\mathrm{AC}$ changed to $88.9 \mathrm{~m}^{2} / \mathrm{g}$ and $3.9 \mathrm{~nm}$, respectively. The change of the surface area of the STE samples can possibly be attributed to the higher proportion of organic constituents present after ST and their removal upon AC. The surface area of the STE samples after calcination is in each case significantly lower than that of the STH samples, while the average pore diameters are in the same range.

The XRD pattern after calcination (Table 2) showed that all samples were nanocrystalline $\mathrm{CeO}_{2}$ with similar particle sizes in the range $3.5-5.5 \mathrm{~nm}$ (calculated by the Scherrer equation based on the strongest peak at $28.6^{\circ}$ ). Interestingly, this was only half the size than that of the particles obtained by calcination only, i.e. without ST. For comparison, we also analyzed the particle sizes of two samples after ST prior to calcination. The average particle size of $\mathrm{CeB} / \mathrm{AO} / \mathrm{F} 127-\mathrm{STE}$ was $<3 \mathrm{~nm}$ (4.0 $\mathrm{nm}$ after calcination) and that of $\mathrm{CeB} / \mathrm{AO} / \mathrm{F} 127-\mathrm{STH} 5.1 \mathrm{~nm}(5.3 \mathrm{~nm}$ after calcination). The crystallite size of the final material is thus determined by the ST and is not significantly changed when the residual surface groups are removed upon subsequent calcination.

A possible explanation for the different particle sizes (and surface areas) between the AC and STE-AC or STH$\mathrm{AC}$ series is that dissolution-deposition equilibria under solvothermal conditions determine the particle size. Similar results were found for ceria solvothermally treated in different alcohols [25]. The obtained particles are capped by residual (organic) groups which are then removed upon calcination. Only crystallite sizes can be determined by $\mathrm{XRD}$, but no information is obtained about agglomeration/ aggregation of the crystallites. The lower BET surface area in the STE series (see Table 2) may thus be due to a more pronounced agglomeration/aggregation of the nanocrystals. In contrast, when the initially obtained gels were calcined
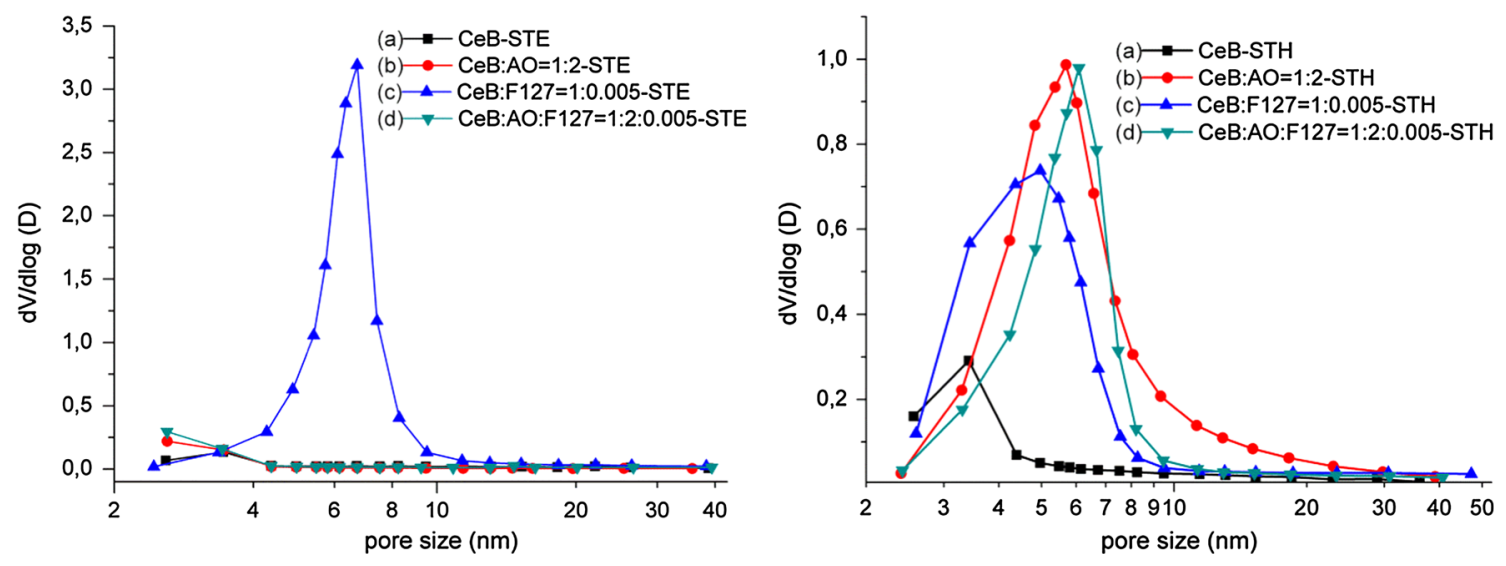

Fig. 4 Pore size distribution for different samples after STE (left) and STH (right) treatment 

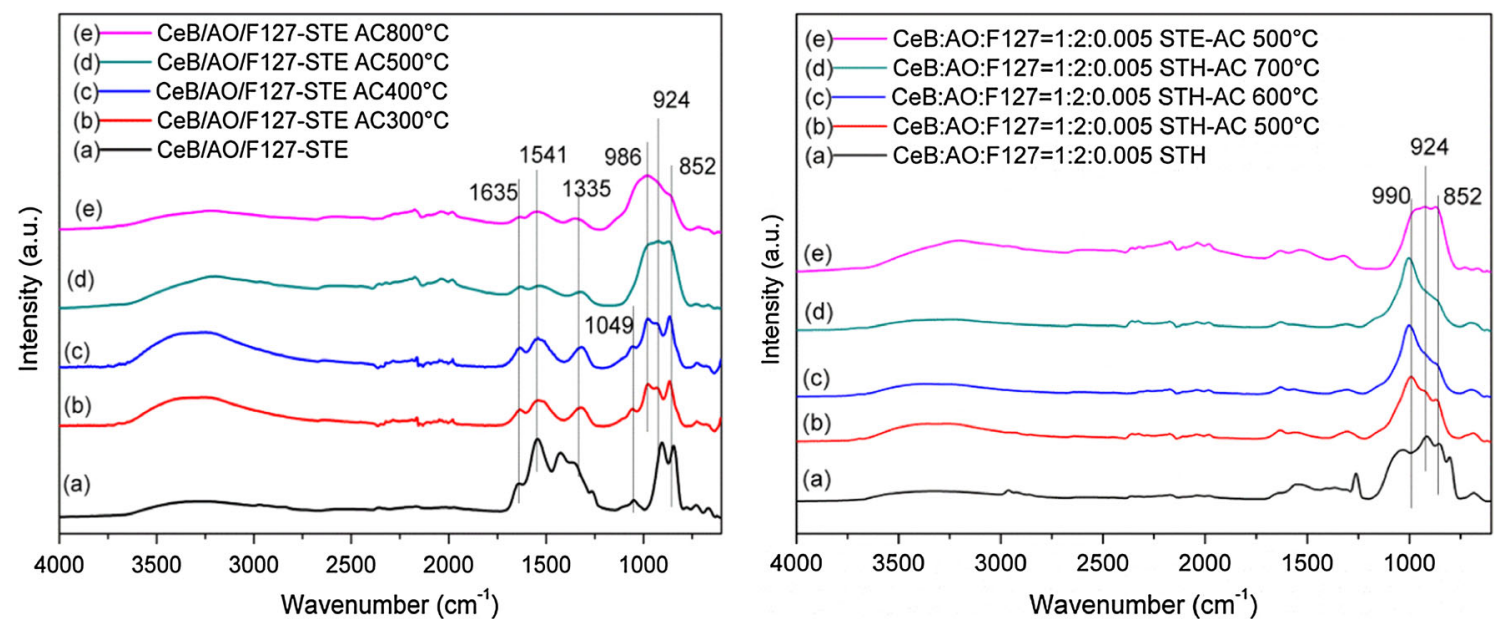

Fig. 5 IR spectra of CeB/AO/F127-STE (left) and CeB/AO/F127-STH (right) calcined in air at different temperatures
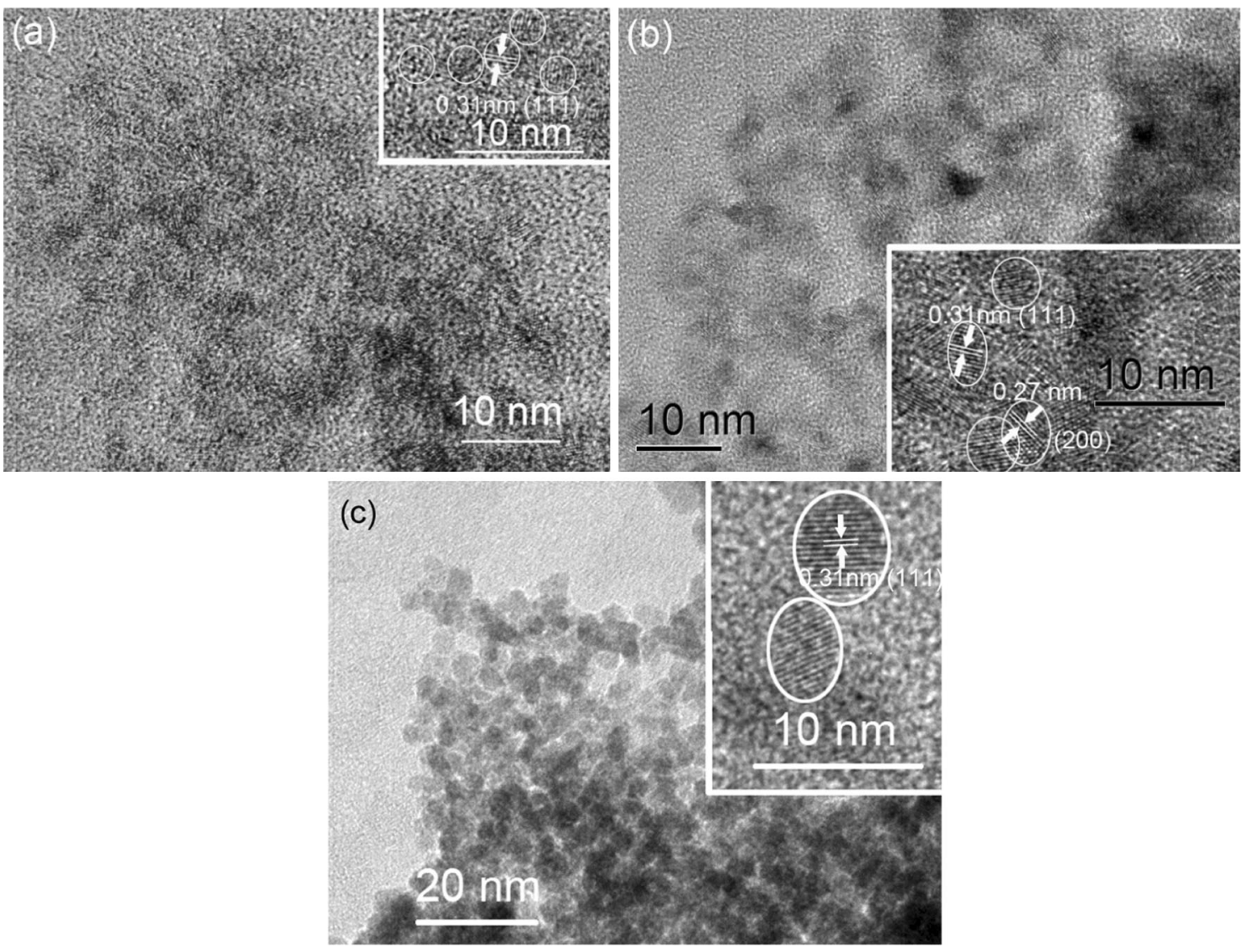

Fig. 6 HRTEM images of sample a CeB/AO/F127-STE, b CeB/AO/F127-STE-AC and c CeB/AO/F127-STH-AC. The insets are higher magnifications of the same image

without prior ST, removal of the organic groups and mass transport coincide and the formation of larger particles is thus favored.

In order to get more information on the influence of calcination, $\mathrm{CeB} / \mathrm{AO} / \mathrm{F} 127-\mathrm{STE}, \mathrm{CeB} / \mathrm{AO} / \mathrm{F} 127-\mathrm{STE}-\mathrm{AC}$ and $\mathrm{CeB} / \mathrm{AO} / \mathrm{F} 127-\mathrm{STH}-\mathrm{AC}$ were characterized by HRTEM (Fig. 6). Only (111) lattice fringes with a distance of $0.31 \mathrm{~nm}$ were observed for the STE and STH-AC samples, while the (200) lattice fringes, with $0.27 \mathrm{~nm}$ distance, were also observed for STE-AC. 


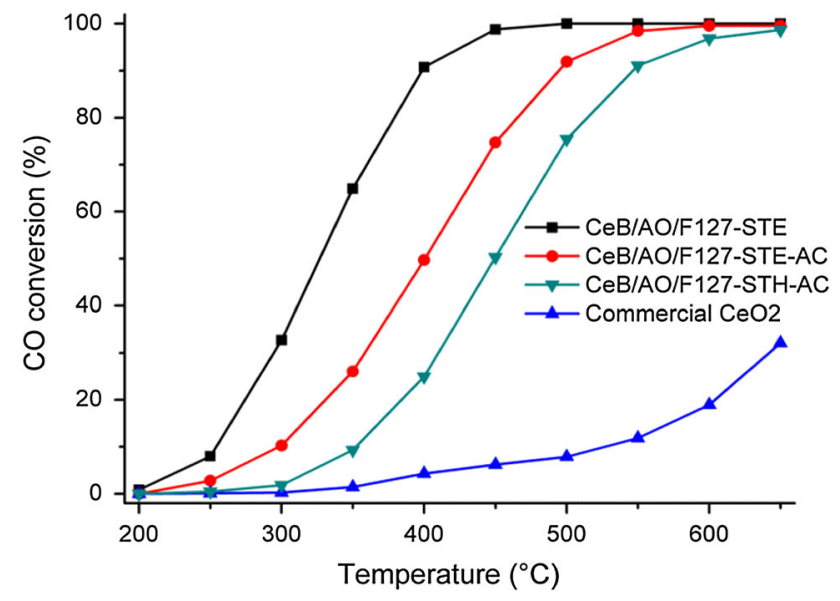

Fig. $7 \mathrm{CO}$ oxidation at different temperatures for $\mathrm{CeO}_{2}$ samples (20 mg), compared with commercial $\mathrm{CeO}_{2}$

\subsection{Catalytic Properties}

The catalytic activity for $\mathrm{CO}$ oxidation was tested for three samples, i.e. $\mathrm{CeB} / \mathrm{AO} / \mathrm{F} 127-\mathrm{STE}, \mathrm{CeB} / \mathrm{AO} / \mathrm{F} 127-\mathrm{STE}-\mathrm{AC}$ and $\mathrm{CeB} / \mathrm{AO} / \mathrm{F} 127-\mathrm{STH}-\mathrm{AC}$ (Fig. 7), with commercial $\mathrm{CeO}_{2}$ serving for comparison. The ignition temperature $\left(\mathrm{T}_{10} \%\right.$, the reaction temperature required for $10 \% \mathrm{CO}$ conversion) of commercial $\mathrm{CeO}_{2}$ is $528{ }^{\circ} \mathrm{C}$ and the lightoff temperature $\mathrm{T}_{90} \%$ (the temperature at which $90 \%$ conversion of $\mathrm{CO}$ is achieved) is $\gg 650{ }^{\circ} \mathrm{C}$ at the conditions specified in the Experimental Section. Both $\mathrm{T}_{10} \%$ and $\mathrm{T}_{90} \%$ are much lower for the three samples prepared in our work (Table 3); the order is $\mathrm{CeB} / \mathrm{AO} / \mathrm{F} 127-\mathrm{STE}<\mathrm{CeB} /$ AO/F127-STE-AC $<$ CeB/AO/F127-STH-AC.

For a better comparison of the catalytic activity of the different samples, the normalized reaction rates at $250{ }^{\circ} \mathrm{C}$ per gram $\left(\mathrm{r}_{250}{ }^{\circ} \mathrm{C}\right)$ and per unit surface area $\left(\mathrm{R}_{250}{ }^{\circ} \mathrm{C}\right)$ are also shown in Table 3. The sequence of $\mathrm{r}_{250}{ }^{\circ} \mathrm{C}$ is $\mathrm{CeB} / \mathrm{AO} /$ F127-STE $>$ CeB/AO/F127-STE-AC $>$ CeB/AO/F127STH-AC $>$ commercial $\mathrm{CeO}_{2}$. The reaction rate at $250{ }^{\circ} \mathrm{C}$ $\left(\mathrm{r}_{250}{ }^{\circ} \mathrm{C}\right)$ of the best sample $\mathrm{CeB} / \mathrm{AO} / \mathrm{F} 127-\mathrm{STE}$ is about 75-times larger than that of commercial $\mathrm{CeO}_{2}$, that at $300{ }^{\circ} \mathrm{C}$ about 125 -times larger.

The CO oxidation activity of the STE and STE-AC catalysts correlates with the specific surface area (Table 3). About three times higher surface area of STE produces about three times higher rates. This can be seen from comparing the reaction rate per surface area, i.e. the amount of $\mathrm{CO}$ converted on a unit surface area of the catalyst at $250{ }^{\circ} \mathrm{C}\left(\mathrm{R}_{250}{ }^{\circ} \mathrm{C}\right)$, which are basically identical. Accordingly, when the specific activities of the two catalysts $\mathrm{CeB} / \mathrm{AO} / \mathrm{F} 127-\mathrm{STE}$ and $\mathrm{CeB} / \mathrm{AO} / \mathrm{F} 127-\mathrm{STE}-\mathrm{AC}$ are compared based on weight, the rates $\mathrm{r}_{250}{ }^{\circ} \mathrm{C}$ (reaction rate of $\mathrm{CO}$ oxidation at $250{ }^{\circ} \mathrm{C} / \mathrm{g}$ ) show an about threefold difference. Commercial ceria roughly fits into this sequence; the specific surface area is about 180-times smaller than that of $\mathrm{CeB} / \mathrm{AO} / \mathrm{F} 127-\mathrm{STE}$, which reduces $\mathrm{r}_{250{ }^{\circ} \mathrm{C}}$ by a factor of 75 .

The third sample $\mathrm{CeB} / \mathrm{AO} / \mathrm{F} 127-\mathrm{STH}-\mathrm{AC}$ exhibits a specific surface area somewhat larger than $\mathrm{CeB} / \mathrm{AO} / \mathrm{F} 127$ STE-AC but shows lower rates (both $\mathrm{R}_{250}{ }^{\circ} \mathrm{C}$ and $\mathrm{r}_{250}{ }^{\circ} \mathrm{C}$ ) by a factor of ten. This must be due to other parameters besides the surface area. In the literature different effects have been made responsible for activity differences of ceria. For example, the crystallite size of $\mathrm{CeO}_{2}$ is known to be a crucial factor for $\mathrm{CO}$ oxidation because size may affect the abundance of oxygen vacancies and thus of associated $\mathrm{Ce}^{3+}$ ions. Smaller crystallite sizes induce a higher fraction of oxygen vacancies due to lower barrier of vacancy formation $[27,28]$. One of the proposed mechanisms for $\mathrm{CO}$ oxidation on $\mathrm{CeO}_{2}$ is oxidation by lattice

Table 3 Properties of different ceria samples $(20 \mathrm{mg}$ ) for CO oxidation

\begin{tabular}{|c|c|c|c|c|c|c|c|c|}
\hline Sample & $\begin{array}{l}P_{X R D} \\
(n m)^{a}\end{array}$ & $\begin{array}{l}\mathrm{S}_{\mathrm{BET}} \\
\left(\mathrm{m}^{2} / \mathrm{g}\right)^{\mathrm{b}}\end{array}$ & $\begin{array}{l}\mathrm{D}_{\mathrm{BJH}} \\
(\mathrm{nm})^{\mathrm{c}}\end{array}$ & $\begin{array}{l}\mathrm{Ce}^{3+} \\
(\%)^{\mathrm{d}}\end{array}$ & $\begin{array}{l}\mathrm{T}_{10 \%} \% \\
\left({ }^{\circ} \mathrm{C}\right)^{\mathrm{e}}\end{array}$ & $\begin{array}{l}\mathrm{T}_{90} \% \\
\left({ }^{\circ} \mathrm{C}\right)^{\mathrm{f}}\end{array}$ & $\begin{array}{l}\mathrm{R}_{2500^{\circ} \mathrm{C}} \\
\left(\mathrm{mol} / \mathrm{s} \mathrm{m}^{2}\right)^{\mathrm{g}}\end{array}$ & $\begin{array}{l}\mathrm{r}_{2500^{\circ} \mathrm{C}} \\
(\mathrm{mol} / \mathrm{s} \mathrm{g})^{\mathrm{h}}\end{array}$ \\
\hline CeB/AO/F127-STE & $<3$ & 277.0 & 3.4 & 12 & 253 & 398 & $2.32 \times 10^{-8}$ & $6.42 \times 10^{-6}$ \\
\hline CeB/AO/F127-STE-AC & 4.0 & 88.9 & 3.9 & 18 & 298 & 494 & $2.52 \times 10^{-8}$ & $2.24 \times 10^{-6}$ \\
\hline $\mathrm{CeB} / \mathrm{AO} / \mathrm{F} 127-\mathrm{STH}-\mathrm{AC}$ & 5.3 & 132.4 & 5.4 & 12 & 353 & 546 & $2.75 \times 10^{-9}$ & $3.64 \times 10^{-7}$ \\
\hline Commercial $\mathrm{CeO}_{2}$ & 57 & 1.5 & 16.8 & $8^{*}$ & 528 & $>>650$ & $5.76 \times 10^{-8}$ & $8.63 \times 10^{-8}$ \\
\hline
\end{tabular}

${ }^{a}$ Crystallite particle size calculated by Scherrer equation from XRD

b BET surface area; error $\pm 5 \%$

c BJH desorption pore diameter; $\pm 0.5 \mathrm{~nm}$ for STE series, $\pm 0.1 \mathrm{~nm}$ for STH series

${ }^{\mathrm{d}} \mathrm{Ce}^{3+}$ ratio from XPS, error \pm 2

${ }^{\mathrm{e}}$ Reaction temperature for $10 \% \mathrm{CO}$ conversion

${ }^{\mathrm{f}}$ Reaction temperature for $90 \% \mathrm{CO}$ conversion

g Normalized specific reaction rates of $\mathrm{CO}$ oxidation on a unit surface area at $250{ }^{\circ} \mathrm{C}$

${ }^{\mathrm{h}}$ Reaction rate of $\mathrm{CO}$ oxidation at $250{ }^{\circ} \mathrm{C} / \mathrm{g}$

* Value taken from Ref. [1] 
oxygen of $\mathrm{CeO}_{2}$ with subsequent creation of oxygen vacancies (and $\mathrm{Ce}^{3+}$ ) which in turn induces formation of active oxygen species [29, 30].

In order to evaluate the $\mathrm{Ce}^{3+}$ proportion, XP spectra were recorded to characterize the three samples (see Fig. 8; Table 3 ). The $\mathrm{Ce} 3 \mathrm{~d}$ region is composed of several doublets (v denotes Ce 3d5/2, u denotes Ce 3d3/2). Specifically, $v_{0}$, $\mathrm{v}^{\prime}, \mathrm{u}_{0}, \mathrm{u}^{\prime}$ belong to $\mathrm{Ce}^{3+}$ species, whereas $\mathrm{v}, \mathrm{v}^{\prime \prime}, \mathrm{v}^{\prime \prime \prime}, \mathrm{u}, \mathrm{u}^{\prime \prime}$ and $\mathrm{u}^{\prime \prime \prime}$ belong to $\mathrm{Ce}^{4+}$ species [31]. In order to estimate the $\mathrm{Ce}^{3+} /\left(\mathrm{Ce}^{3+}+\mathrm{Ce}^{4+}\right)$ ratio, the relative peak area of the $\mathrm{u}_{0}\left(\mathrm{v}_{0}\right)$ and $\mathrm{u}^{\prime}\left(\mathrm{v}^{\prime}\right)$ with respect to the area of the entire Ce $3 \mathrm{~d}$ region was determined [12]. The results (Table 3 ) indicate that the $\mathrm{Ce}^{3+}$ proportion can be influenced by the synthesis parameters to some extent. When CeB/AO/F127-STE-AC and $\mathrm{CeB} / \mathrm{AO} / \mathrm{F} 127-\mathrm{STH}-\mathrm{AC}$ are compared, the use of

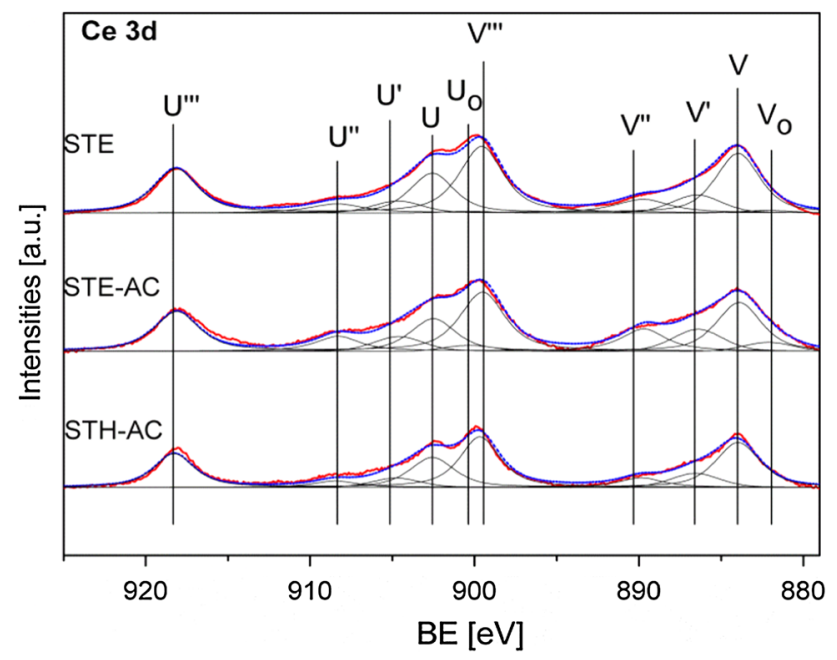

Fig. $8 \mathrm{XP}$ spectra of the Ce $3 \mathrm{~d}$ region for $\mathrm{CeB} / \mathrm{AO} / \mathrm{F} 127-\mathrm{STE}, \mathrm{CeB} /$ $\mathrm{AO} / \mathrm{F} 127-\mathrm{STE}-\mathrm{AC}$ and $\mathrm{CeB} / \mathrm{AO} / \mathrm{F} 127-\mathrm{STH}-\mathrm{AC}$ (red raw spectrum, blue peak sum after fitting, black fitted peaks)

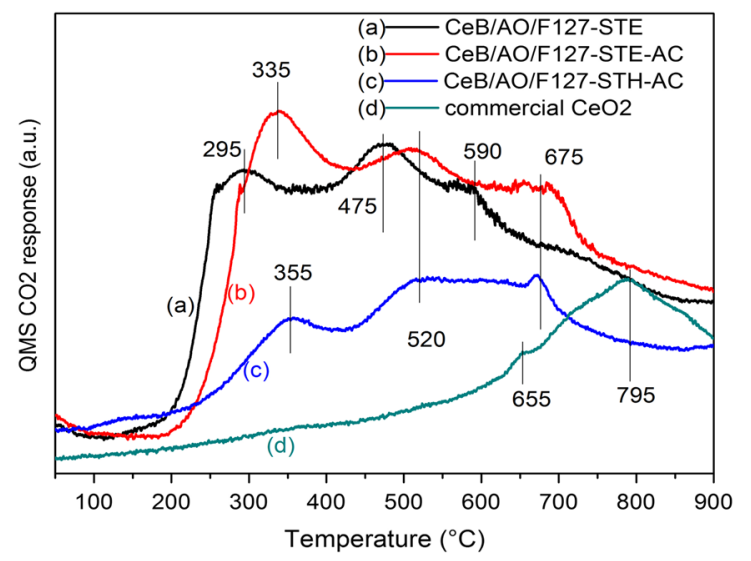

EtOH for solvothermal processing results in a higher $\mathrm{Ce}^{3+}$ proportion. This may be due to the fact that EtOH is reductive and can be oxidized to acetaldehyde or carboxylate [25]. Besides the solvent, the post-synthesis treatment can also influence the $\mathrm{Ce}^{3+}$ proportion. While $\mathrm{CeB} / \mathrm{AO} /$ F127-STE had only $12 \% \mathrm{Ce}^{3+}$, the $\mathrm{Ce}^{3+}$ proportion of $\mathrm{CeB} / \mathrm{AO} / \mathrm{F} 127-\mathrm{STE}-\mathrm{AC}$ increased to $18 \%$ when calcined in air. One possible explanation is that decomposition of the carboxylate group might require some oxygen from the ceria, causing oxygen deficiency.

Nevertheless, a correlation between the $\mathrm{Ce}^{3+}$ proportion and the specific catalytic activity was not observed. It may explain the difference between the specific catalytic activity of the STH-AC and STE-AC samples. On the other hand, however, STE and STH-AC have a comparable $\mathrm{Ce}^{3+}$ proportion but STE has one magnitude higher catalytic activity.

In $\mathrm{CO}$ temperature programmed reaction (CO-TPR) experiments, $\mathrm{CO}_{2}$ and $\mathrm{H}_{2}$ evolution were observed when the samples were exposed to $\mathrm{CO}$ and heated to $900{ }^{\circ} \mathrm{C}$ (Fig. 9). The $\mathrm{CO}_{2}$ evolution showed three peaks for all samples, i.e. $<400,450-600$, and $>650{ }^{\circ} \mathrm{C}$. In the literature, these features were attributed to the removal of surface lattice oxygen, water gas shift between $\mathrm{CO}$ and surface $\mathrm{OH}$ groups $\left(\mathrm{CO}+\mathrm{OH} \rightarrow 1 / 2 \mathrm{H}_{2}+\mathrm{CO}_{2}\right)$, and extraction of bulk oxygen, respectively [32]. Interestingly, the low temperature $\mathrm{CO}_{2}$ peak of STE is shifted by around $50{ }^{\circ} \mathrm{C}$ to low temperature relative to the STE-AC and STHAC samples. In addition, STE also exhibits, besides the main $\mathrm{H}_{2}$ peak at $500-570{ }^{\circ} \mathrm{C}$ (which is due to the water gas shift reaction), an additional feature at around $320^{\circ} \mathrm{C}$, which was not observed for the other samples. The $\mathrm{H}_{2}$ evolution at low temperature for STE could be attributed to reactions involving the residual organic group after the synthesis. This would also explain the shift of $\mathrm{CO}_{2}$ evolution to lower temperature for STE.

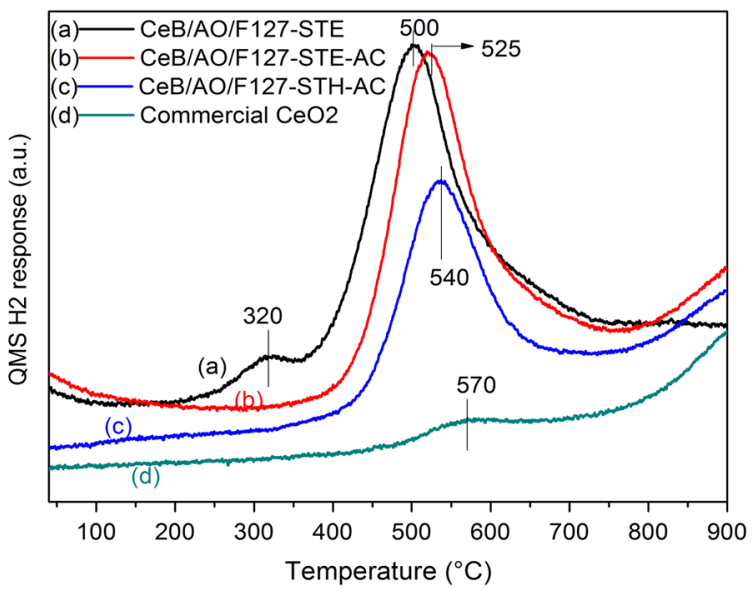

Fig. $9 \mathrm{CO}_{2}$ (left) and $\mathrm{H}_{2}$ (right) evolution during CO-TPR over different $\mathrm{CeO}_{2}$ samples $(20 \mathrm{mg})$ 
As discussed above, $\mathrm{CO}$ oxidation by ceria depends on the oxygen vacancies $\left(\mathrm{Ce}^{3+}\right)$, but the surface $\mathrm{OH}$ can also contribute to the reaction. The same catalytic activity of STE and STE-AC may be due to the compensation of the $\mathrm{Ce}^{3+}$ proportion (which is lower for STE) and the influence of highly reactive $\mathrm{OH}$ groups resulting from the residual organic species in the STE sample. STE-AC and STH-AC do not contain such $\mathrm{OH}$ groups, as the organic species were largely removed during the calcination. Therefore, despite the missing $\mathrm{OH}$ groups, the specific activity exhibited by STE-AC is the result of high $\mathrm{Ce}^{3+}$ content. A possible explanation for the different specific catalytic activity may thus be the different $\mathrm{CeO}_{2}$ surface states formed in the different post-synthesis treatments, and the reductive ability of EtOH might be a key factor.

\section{Conclusions}

We have shown in this work that the use of cerium alkoxides as sol-gel precursor for ceria has clear advantages compared with $\left(\mathrm{NH}_{4}\right)_{2}\left[\mathrm{Ce}\left(\mathrm{NO}_{3}\right)_{6}\right]$. Gels were prepared from acetaldoximate-substituted cerium $t$-butoxide in the presence of the surfactant F127. The latter served to create interparticle porosity after calcination. However, the postsynthesis treatment of the obtained gels had a larger influence on the resulting specific surface area than the composition of the starting mixture. ST in either ethanol or water resulted in materials with distinctly higher specific surface areas and smaller crystallite size than by calcination alone. Specific surface areas of up to $277 \mathrm{~m}^{2} / \mathrm{g}$ were obtained which is unprecedented for ceria (commercial ceria ranges around $2 \mathrm{~m}^{2} / \mathrm{g}$ ). Post-synthesis calcination of the gels allows removing of the residual organic groups. Both the solvent used for ST and the calcination process can influence the $\mathrm{Ce}^{3+} / \mathrm{Ce}^{4+}$ ratio. The highest $\mathrm{Ce}^{3+}$ proportion was $18 \%$ for $\mathrm{CeB} / \mathrm{AO} / \mathrm{F} 127-\mathrm{STE}-\mathrm{AC}$.

Tests of $\mathrm{CO}$ oxidation on selected samples indicated that a high catalytic activity is related to a high surface area and the surface groups created by the post-synthesis treatment. With regard to the latter, ST of the samples in ethanol proved to be particularly efficient. The sample with highest surface area $\left(277 \mathrm{~m}^{2} / \mathrm{g}\right)$ from ST with ethanol outperformed commercial ceria by a factor of 75 .

Acknowledgments This project was funded by the Austrian Science Funds (FWF) in the framework of the Doctoral School "Building Solids for Function" (Project W1243) and SFB "Functional Oxide Surfaces and Interfaces" (Project F45). The authors thank Elisabeth Eitenberger for SEM measurements, Christina Artner for the XRD measurements, and Stefan Löffler and Michael StögerPollach for HRTEM characterization at the USTEM of TU Wien.

Open Access This article is distributed under the terms of the Creative Commons Attribution License which permits any use, distribution, and reproduction in any medium, provided the original author(s) and the source are credited.

\section{References}

1. Hua G, Zhang L, Fei G, Fang M (2012) J Mater Chem 22:6851

2. Trovarelli A (1996) Catal Rev Sci Eng 38:439

3. Guzman J, Carrettin S, Corma A (2005) J Am Chem Soc $127: 3286$

4. Smolentseva E, Simakov A, Beloshapkin S, Estrada M, Vargas E, Sobolev V, Kenzhin R, Fuentes S (2012) Appl Catal B 115:117

5. Wang J, Shen M, Wang J, Gao J, Ma J, Liu S (2011) Catal Today 175:65

6. Wang B, Wu X, Ran R, Si Z, Weng D (2012) J Mol Catal A 356:100

7. He F, Meng X, Shen X, Xiang J, Wang P (2012) J Sol-Gel Sci Technol 61:551

8. Zhou K, Wang X, Sun X, Peng Q, Li Y (2005) J Catal 229:206

9. Li X, Lu G, Qiao D, Wang Y, Guo Y, Guo Y (2011) Catal Lett 141:452

10. Hassanzadeh-Tabrizi SA, Taheri-Nassaj E (2011) J Amer Ceram Soc $94: 3488$

11. Pouretedal HR, Tofangsazi Z, Keshavarz MH (2012) J Alloys Comp 513:359

12. Qi L, Yu Q, Dai Y, Tang CJ, Liv LJ, Zhang HL, Gao F, Dong L, Chen Y (2012) Appl Catal B 119:308

13. Avellaneda CO, Berton MAC, Bulhoes LOS (2008) Solar Energy Mater Solar Cells 92:240

14. Ferrara M, Piscopiello E, Laera A, Pilloni L, Mazzarelli S, Tapfer L (2011) J Sol-Gel Sci Technol 60:333

15. Keomany D, Poinsignon C, Deroo D (1994) Solar Energy Mater Solar Cells 33:429

16. Nakagawa K, Murata Y, Kishida M, Adachi M (2005) Chem Lett $34: 296$

17. Nakagawa K, Murata Y, Kishida M, Adachi M, Hiro M, Susa K (2007) Mater Chem Phys 104:30

18. Chen D, Cao L, Huang F, Imperia P, Cheng YB, Caruso RA (2010) J Am Chem Soc 132:4438

19. Chen R, Trieu V, Natter H, Stowe K, Maier WF, Hempelmann R, Bulan A, Kintrup J, Weber R (2010) Chem Mater 22:6215

20. Yang J, Peterlik H, Lomoschitz M, Schubert U (2010) J NonCryst Solids 356:1217

21. Baumann SO, Puchberger M, Schubert U (2011) Dalton Trans 40:1401

22. Gradeff PS, Schreiber FG, Brooks KC, Sievers RE (1985) Inorg Chem 24:1110

23. Evans WJ, Deming TJ, Olofson JM, Ziller JW (1989) Inorg Chem 28:4027

24. Sing KSW, Everett DH, Haul RAW, Moscou L, Pierotti RA, Rouquerol J, Siemieniewska T (1985) Pure Appl Chem 57:603

25. Slostowski C, Marre S, Babot O, Toupance T, Aymonier C (2012) Langmuir 28:16656

26. Ho C, Yu JC, Kwong T, Mak AC, Lai S (2005) Chem Mater 17:4514

27. Zhou XD, Huebner W (2001) Appl Phys Lett 79:3512

28. Wum L, Wiesmann HJ, Moodenbaugh AR, Klie RF, Zhu Y, Welch DO, Suenaga M (2004) Phys Rev B 69:125415

29. Lee Y, He G, Akey AJ, Si R, Flytzani-Stephanopoulos M, Herman IP (2011) J Am Chem Soc 133:12952

30. Pong WY, Chang HY, Chen HI, Chang JR (2008) Surf Rev Lett 15:123

31. Beche E, Charvin P, Perarnau D, Abanades S, Flamant G (2008) Surf Interf Anal 40:264

32. Wu Z, Li M, Overbury SH (2012) J Catal 285:61 